\title{
Match Analysis of The Indonesian Basketball League Competition Season 2018/2019
}

\author{
Arif Rizki Zesfi ${ }^{1, *}$, Novita Intan Arovah ${ }^{1}$ \\ ${ }^{1}$ Faculty of Sport Sciences, Universitas Negeri Yogyakarta, Yogyakarta, Indonesia \\ Corresponding author.Email: arifrizki.2018@student.uny.ac.id
}

\begin{abstract}
Indonesian Basketball League (IBL) match session 2018/ 2019 performance data are available in the public domain. However, the data have not been adequately analyzed for evaluating team performance and for developing strategies for programing athlete training. Furthermore, factors contributing to the winning of the Stapac club in the session have not been explored. Therefore, this study aimed to analyze the IBL 2018/2019 session and factors contributing to Stapac in winning this session. This research was a descriptive study on secondary data from the 2018/2019 IBL match performance which was available from the IBL website (www.iblindonesia.com). The data were analyzed descriptively for each performance which included field goals (FG), assists (AST), 3-points (3P), 2-points (2P), turnover (TO), rebounds (REB), steals (STL), free throw (FT), foul (PF) and block (BLK). The results showed that the average team performance compared to STAPAC during the session were $\mathrm{FG}=41 \%$ vs $46 \%$, $\mathrm{AST}=17$ times vs 15 times, $3 \mathrm{P}=29$ vs $32 \%, 2 \mathrm{P}=47 \%$ vs $53 \%$, $\mathrm{TO}=$ 15 times vs 15 times, REB $=43$ times vs 45 times, $\mathrm{STL}=9$ times vs 10 times, $\mathrm{FT}=64$ times vs $62 \%, \mathrm{PF}=\mathrm{vs} 20$ times, and $\mathrm{BLK}=3$ times vs 3 times. STAPAC team performed better compared to other teams on the FG, $2 \mathrm{P}$, 3P, AST, and PF performances. Coaches and athletes, therefore, need to emphasize these skills for winning the competition.
\end{abstract}

Keywords: match statistics, Indonesian basketball league

\section{INTRODUCTION}

Basketball is one of the most popular sports in Indonesia [1]. Basketball is played by two teams of five players, each with the aim to shoot and place the ball into the opponent's basket while preventing the other team from placing the ball in its own's basket. Scores are gained when a team successfully placed the ball on the opponent's basket [2]. The basketball competition starts from the regional level to the professional and even international level [3]. At the national level, the Indonesian Basketball League (IBL) is organized since 2003, and have provided opportunities for eligible Indonesian teams to compete.

The teams that participated in the 2018/2019 IBL series were Satria Muda Pertamina Jakarta, Pelita Jaya EMP Jakarta, Stapac Jakarta, Hangtuah Sumsel, Prawira Bandung, Pacific Caesar Surabaya, Bima Perkasa Jogja, Satya Wacana Salatiga, NSH Jakarta, Bogor Siliwangi. Although many teams competed, from the first rolling in 2003 to the 2018/2019 series, only 4 teams were recorded as champions, which were Satria Muda
Pertamina Jakarta (nine times), Stapac Jakarta (five times), Pelita Jaya EMP Jakarta (one time), CLS Knights Surabaya (one time) [4].

IBL in every match has collected match statistics, that record important events that occur in a match [5]. The statistical data available on the website https://iblindonesia.com. The data are generated using computer-based software developed by the federation of international basketball association (FIBA). The software called "FIBA-livestats". The software produces the statistical data of matches, instantly. Statistical data in the IBL presented in the form of field goal, 2point, 3- point, free throw, total rebound, assist, steal, block, turnover, personal foul.

Although these statistics are important and have become an integral part of basketball, there are still many players, coaches, and clubs that have not fully understood the importance of statistics in basketball and have not used the data to evaluate teams' performance during matches to develop an appropriate training program for teams and athletes [6]. Furthermore, factors contributing to the winning of the STAPAC club also have not been 
explored. Therefore, this study aimed to analyze the IBL 2018/ 2019 session and factors contributing to STAPAC in winning the IBL 2018/2019 session.

\section{METHOD}

\subsection{Research Design}

This study was quantitative descriptive research on the IBL 2018/2019 session data available on www.iblindonesia.com [7].

\subsection{Data Sources, Research Data, Research Subjects, and Instruments}

This study utilized secondary data of the match performance from the Indonesian Basketball League 2018/2019. The document was owned by the Indonesian Basketball League Council but could be used freely by the public. The subjects of this study were the data gathered from the teams' performances in the Indonesian Basketball League 2018/2019. The total number of the team were 10 teams which covered Satria Muda Pertamina Jakarta, Pelita Jaya EMP Jakarta, Stapac Jakarta, Hangtuah Sumsel, Prawira Bandung, Pacific Caesar Surabaya, Bima Perkasa Jogja, Satya Wacana Salatiga, NSH Jakarta, Bogor Siliwangi.

The team competed in the Indonesian Basketball League 2018/2019. Semarang in series 1 (30 November - 2 December 2018), Jakarta in series 2 (7-9 December 2018), Bali in series 3 (1416 December 2018), Solo in series 4 (10-12 January 2019), Bandung in series 5 (25-27 January 2019), Surabaya in series 6 (1-3 February 2019), Malang in series 7 (8-10 February 2019), and Yogyakarta in series 8 (15-17 February 2019). The data were extracted from the FIBA Livestats match statistics software used in the 2018/2019 IBL series.

\subsection{Data Collection and Analysis Techniques}

Table 1 illustrates the template in which the data of the IBL 2018/2019 match statistics were gathered from the website www.iblindonesia.com.

Table 1. Data Collection Template

\begin{tabular}{|c|c|c|}
\hline $\begin{array}{c}\text { Performance } \\
\text { Team }\end{array}$ & $\begin{array}{c}\text { Statistical } \\
\text { Component }\end{array}$ & $\begin{array}{c}\text { Performance } \\
\text { Team }\end{array}$ \\
\hline & FG & \\
\hline & $2 P$ & \\
\hline & $3 P$ & \\
\hline
\end{tabular}

\begin{tabular}{|l|c|l|}
\hline & $F T$ & \\
\hline & $R E B$ & \\
\hline & AST & \\
\hline & $S T L$ & \\
\hline & BLK & \\
\hline & TO & \\
\hline & PF & \\
\hline
\end{tabular}

Note:

FG : Field Goal which is the percentage of successful shots ( 2 and 3 points).

$2 \mathrm{P}: 2$ Points which is the percentage of successful 2-point shots during the match.

3P : 3 Points which is the percentage of successful 3-point shots during the match.

FT : Free Throw which is the percentage of successful 1-point shots during the match.

REB : Total Rebound which is the number of balls obtained during attack or defense.

AST : Assist which is passing which can be converted into points by teammates.

STL : Steal, which is the number of successful attempts to steal the ball from the opponent during the match.

BLK : Block which is the number of successful blocking opponent shots during the match.

TO : Turnover which is the number of mistakes made by players during the match.

PF : Personal Foul which is the number of fouls committed during the match.

Statistical analyses of the matches on the teams's performanced were carried out descriptively. Statistical analysis of each component of the basketball game technique with the following calculations to calculate the mean of all matches, on the component field goals, 2 points, 3 points, free throws, assists, rebounds, turnovers, steals, blocks, personal fouls:

$$
\begin{array}{ll}
\bar{X}= & \frac{\sum X_{i}}{n} \\
\overline{\mathrm{x}} & =\text { average } \\
\mathrm{Xi} & =\text { data value } \\
\mathrm{n} & =\text { number of match }
\end{array}
$$


The results of match statistics were used to determine statistical components of specific performances obtained by all team including the Stapac Jakarta team when competing in the 2018/2019 Indonesian Basketball League season.

Furthermore, to find out the level of categories carried out in this study, it was preceded by ascertaining the statistical results of the Stapac Jakarta match when competing in the Indonesian Basketball League on November 30, 2018 - March 23,2019 , then entered into the quartile formula

$$
\begin{aligned}
& \text { Q1=High } \\
& \text { Q2=Above the median } \\
& \text { Q3=Belowmedian } \\
& \text { Q4=Low }
\end{aligned}
$$$$
\text { Location of } \mathrm{Qi}=\text { Data } k e \frac{i(n+1)}{4}
$$

\section{RESULTS}

Figure 1 illustrates the performances of all teams including Stapac when competing in the 2018/2019 Indonesian Basketball League season.

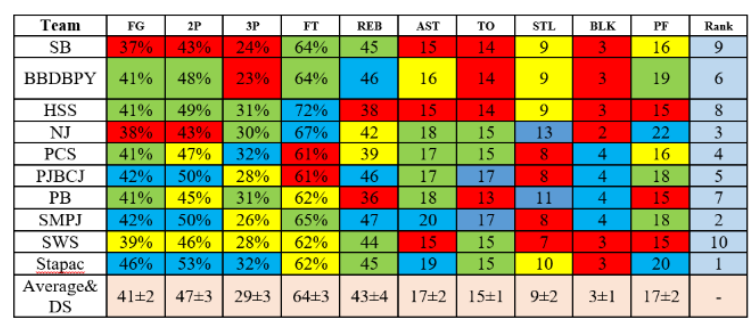

Figure 1. All Team's Statistical Component

Note:

$\begin{array}{ll}\text { SB } & \text { : Siliwangi Bogor, } \\ \text { BBDBPY } & \begin{array}{l}\text { :Bank BPD DIY Bima Perkasa } \\ \text { Yogyakarta, }\end{array} \\ \text { HSS } & \text { : Hangtuah Sumatera Selatan, } \\ \text { NJ } & \text { : NSH Jakarta, } \\ \text { PCS } & \text { : Pacific Caesar Surabaya, } \\ \text { PJBCJ } & \text { : Pelita Jaya Basketball Club Jakarta, } \\ \text { PB } & : \text { Prawira Bandung, } \\ \text { SMPJ } & \text { : Satria Muda Pertamina Jakarta, } \\ \text { SWS } & \text { : Satya Wacana Salatiga. dan } \\ \text { SJ } & \text { : Stapac Jakarta. }\end{array}$

As seen in in Figure 1, Stapac performed in high category in the field goal, 2-point, 3-point, assist and personal foal and ranked first in the IBL 2018/2019 competition. On the other hand, the runner up which was the Satria Muda Pertamina Jakarta performed in high category in 6 components which were field goal, 2 points, rebound, assist, turn over and block. Table 2 further highlights the performance category of Stapac in each component.

Table 2. Stapac Statistical Component Criteria Compared to Other Teams.

\begin{tabular}{|l|c|}
\hline Criteria & Component \\
\hline High & $\begin{array}{c}\mathrm{FG}(40 \%), \quad 2 \mathrm{P}(53 \%), \\
3 \mathrm{P}(32 \%), \operatorname{AST}(19), \mathrm{PF}(20)\end{array}$ \\
\hline Above the Median & $\mathrm{REB}(45), \mathrm{TO}(15), \mathrm{STL}(10)$ \\
\hline Below the Median & $\mathrm{FT}(62 \%)$ \\
\hline Low & $\mathrm{BLK}(3)$ \\
\hline
\end{tabular}

\section{DISCUSSION}

The average of the statistical components of all teams in IBL 2018/2019 matches were $\mathrm{FG}=41 \%$, $2 \mathrm{P}=47 \%, 3 \mathrm{P}=29 \%, \mathrm{FT}=64 \%, \mathrm{REB}=43, \mathrm{AST}=17$, $\mathrm{TO}=15, \mathrm{STL}=9, \mathrm{BLK}=3, \mathrm{PF}=17$, while Stapac were $\mathrm{FG}=46 \%, 2 \mathrm{P}=53 \%, \quad 3 \mathrm{P}=32 \%, \quad \mathrm{FT}=62 \%$, $\mathrm{REB}=45, \quad \mathrm{AST}=19, \mathrm{TO}=15, \quad \mathrm{STL}=10, \quad \mathrm{BLK}=3$, $\mathrm{PF}=20$. The mean statistical components of Stapac were higher compared to other teams in five components, namely: FG, 2P, 3P, AST, PF.

The five components that are the focus of discussion, field goals have good control in this match because they have high rebounds, high assists, and are able to minimize turnover. The finding is in line with research [8] which showed that the factors that influenced the East Java team's victory were the field goals, free throws, rebounds, assists, and steals components. In contrast to research [9]. According to the study these components provide a significant advantage for a team for winning the match.

The results indicate that Stapac Jakarta excelled in field goals and 2 points. Field goal is a general term or the score in a game, including three points [10], while 2 points is the number obtained if a team enters the ball from within the three-point line (except free throws). Of all the matches that have been played, Stapac Jakarta has the highest percentage of field goals at $46 \%$. Stapac Jakarta excelled in the field goal statistical component compared to other Indonesian Basketball League 
2018/2019 teams because Stapac Jakarta was able to maximize all opportunities thus they can score as many points as possible, especially in the 2-point match statistics component, In addition to high points, another factor that affects provide the advantage of this match is that Stapac has good assists, which was 19 times. Stapac also demonstrates high performance on assist, which is an influential factor in match mastery [11]. However, Stapac was unable to minimize turnover. Based on a study [12], reducing turnover means increasing effective ball possession. Thus, it limited Stapac to having better ball possession. Other factors that influence excellence are free throws and rebounds. This affected the Stapac team to play quite well this season. In line with research [13] the maturity of the team to score points is related to assists and turnover so that the team can have better opportunities to win the game.

\section{CONCLUSION}

This study provides a match analysis for the IBL 2018/2019 season that can be utilized by coaches and athletes to evaluate their performance and to develop a strategy for athletic training to increase the chance of winning. Several factors that contributed to Stapac's win in the IBL 2018/2019 are FG, 2P, 3P, AST, and PF components. Coaches and athletes, therefore, need to emphasize these skills for winning the competition.

\section{ACKNOWLEDGMENT}

The author would like to thank the IBL for providing match statistics for the 2018/2019 season.

\section{REFERENCES}

[1] Junaidi, IA (2018). Improving Basketball Chest Pass Skills Through Peer Teaching Methods for Students of the Sports Education Study Program. Journal of Penjaskesrek, 5(9), 37-43.

https://doi.org/10.1017/CBO9781107415324.0 04

[2] FIBA. (2018). 2018 Official Basketball Rules.

[3] Darumoyo, K. (2019). Biomechanical analysis of Klay Thompson's three point shoot from various angles in the United States basketball team match at the 2014 FIBA World Cup Final. JPOS (Journal Power Of Sports).

[4] IBL indonesia. Source: http://www.Iblindonesia.com, accessed on 22 September 2020 at 07:48 WIB.
[5] Kurniawan, RD (2018). Game Effectiveness of Indonesian Basketball League (Ibl) 2017/2018 Participants in the Semifinals and Finals. 1-10.[6].Geidl, W., Schlesinger, S., Mino, E., Miranda, L., \& Pfeifer, K. Doseresponse relationship between physical activity and mortality in adults with noncommunicable diseases: a systematic review and meta-analysis of prospective observational studies.International Journal of Behavioral Nutrition and Physical Activity, 17 (109), 1-18. https://doi.org/10.1186/s12966020-01007-5. 2020.

[6] Sampaio, J., McGarry, T., Calleja-González, J., Jiménez Sáiz, S., Schelling I Del Alcázar, X., \& Balciunas, M. (2015). Exploring game performance in the National Basketball Association using player tracking data. PLoS ONE, 10(7), 1-14.

[7] Yusuf, Muri. (2014). Research methods are quantitative, qualitative, and combined research. Jakarta: Kencana.

[8] Ramadhani \& Hariyanto. (2017). Analysis of Technical Ability to Play Ku14 Basketball in the 2017 National Championship in Jakarta Based on Statistical Data. 1-11.

[9] Fitriasmara, D. (2017). Analysis of the Excellence of the Sidoarjo Men's Basketball Team in East Java Province Province 2015. Journal of Sports Achievement, 2.

[10] Indonesian Basketball Association. 2005. Rules of the game of basketball. Jakarta: Perbasi.

[11] Joshua, Ade Iriani, RL (2015). Factors Affecting the Final Result of the Match Basketball in the National Basketball League (NBL) For Information In Coach Decision Making.

[12] Fylaktakidou, A., Tsamourtzis, E., \& Zaggelidis, G. (2012). The Turnovers Analysis to the Women's National League Basketball Games. Sport Science Review, 20(3-4), 6983.

[13] García, J., Ibáñez, SJ, De Santos, RM, Leite, N., \& Sampaio, J. (2013). Identifying basketball performance indicators in regular season and playoff games. Journal of Human Kinetics, 36(1), 161-168. https://doi.org/10.2478/hukin-2013-0016 